\title{
Large schwannoma of the sciatic nerve
}

\author{
Owen Godkin, ${ }^{1}$ Prasad Ellanti, ${ }^{2}$ Gary O'Toole ${ }^{1}$
}

${ }^{1}$ Cappagh National

Orthopaedic Hospital,

Dublin, Ireland

${ }^{2}$ Department of Orthopaedic

Cappagh National Orthopaedic

Hospital, Dublin, Ireland

\section{Correspondence to}

Dr Owen Godkin

owen.godkin@gmail.com

Accepted 18 October 2016

\section{DESCRIPTION}

A 40-year-old woman was referred with an 8month history of fullness of the right posterior thigh. This was associated with pain, primarily on sitting and occasional radicular pain down the ipsilateral leg. On examination a mobile, firm lump was identified that was tender to palpate and which also elicited a shooting pain down the leg on examination. MRI demonstrated a well-defined multiloculated mass $9 \mathrm{cms} \times 6 \mathrm{cms}$ which appeared to arise from the sciatic nerve, raising suspicion for a schwannoma (figure 1). A biopsy confirmed the diagnosis of schwannoma. Surgical excision

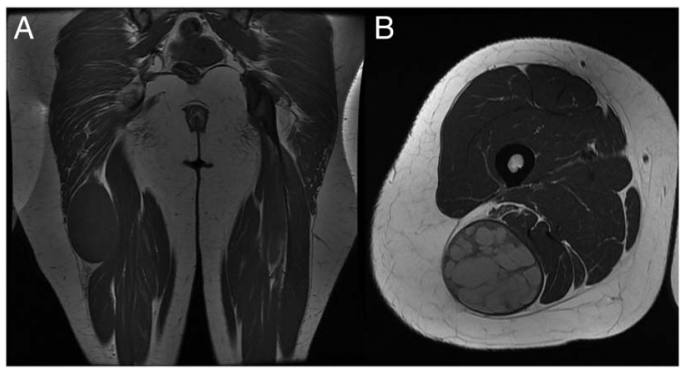

Figure 1 A coronal (A) and axial (B) T1-weighted MRI of a well-defined multiloculated mass $9 \mathrm{cms} \times 6 \mathrm{cms}$ arising from the sciatic nerve.

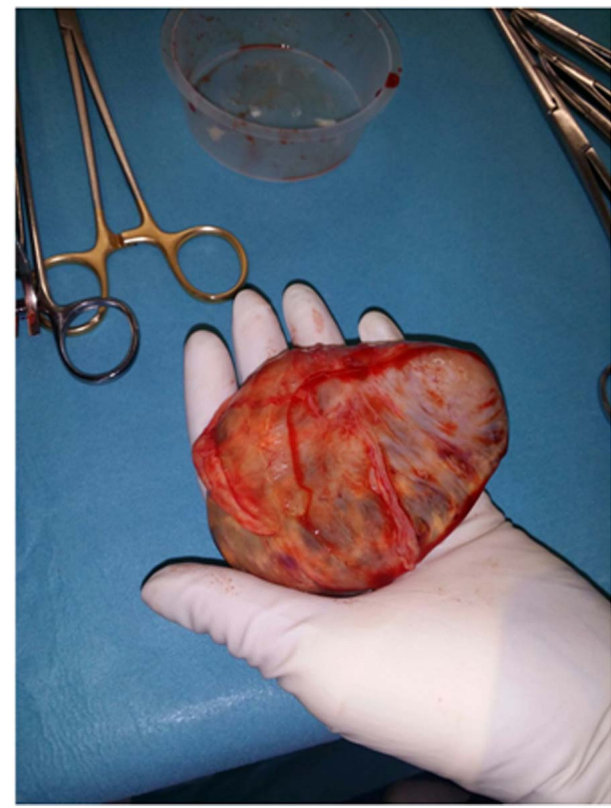

Figure 2 Schwannoma lesion excised en masse. was undertaken, carefully dissecting the lesion from the sciatic nerve (figure 2). The patient had an uneventful postoperative recovery without neurovascular deficits.

A schwannoma is the most common benign peripheral nerve sheath tumour composed of Schwann cells. ${ }^{1}$ It represents $8 \%$ of all soft tissue tumours with sciatic nerve involvement being $<1 \%$. $^{2}$ Symptoms of nerve sheath tumours relate to nerve function and surrounding structures. Direct compression from large lesions can present with symptoms similar to those of sciatica. The diagnoses of sciatic nerve-associated schwannomas are typically made with MRI often subsequent to a normal lumbar spine MRI. Treatment of this epineurium encapsulated tumour is by delicate excision, en masse and nerve preservation followed by histopathology for definitive diagnosis.

\section{Learning points}

At $8 \%$ schwannomas are the most common soft tissue tumour.

- Symptoms of schwannomas are dependent on the location and nerve association.

- Treatment involves complete capsule enucleation to reduce recurrence.

Contributors statement $\mathrm{OG}$ and PE: Image and data gathering. Writing of manuscript. GOT: Clinical supervisor and treated the patient.

Competing interests None declared.

Patient consent Obtained.

Provenance and peer review Not commissioned; externally peer reviewed.

\section{REFERENCES}

1 Kralick F, Koenigsberg R. Sciatica in a patient with unusual peripheral nerve sheath tumors. Surg Neurol 2006;66:634-7.

2 Blanchard C, Dam-Hieu P, Zagnoli F, et al. [Chronic sciatic pain caused by sciatic nerve schwannoma]. Rev Med Interne 2008;29:748-50. 
Copyright 2016 BMJ Publishing Group. All rights reserved. For permission to reuse any of this content visit http://group.bmj.com/group/rights-licensing/permissions.

BMJ Case Report Fellows may re-use this article for personal use and teaching without any further permission.

Become a Fellow of BMJ Case Reports today and you can:

- Submit as many cases as you like

- Enjoy fast sympathetic peer review and rapid publication of accepted articles

- Access all the published articles

- Re-use any of the published material for personal use and teaching without further permission

For information on Institutional Fellowships contact consortiasales@bmjgroup.com

Visit casereports.bmj.com for more articles like this and to become a Fellow 